\title{
The Opposite of Dante's Hell? The Transfer of Ideas for Social Housing at International Congresses in the 1850s-1860s
}

Carmen Van Praet - Liberaal Archief/Ghent University

Kramersplein 23

9000 Ghent

Belgium

+3292217505

carmen.vanpraet@liberaalarchief.be

\begin{abstract}
With the advent of industrialization, the question of developing adequate housing for the emergent working classes became more pressing than before. Moreover, the problem of unhygienic houses in industrial cities did not stop at the borders of a particular nation-state; sometimes literally as pandemic diseases spread out 'transnationally'. It is not a coincidence that in the nineteenth century the number of international congresses on hygiene and social topics expanded substantially. However, the historiography about social policy in general and social housing in particular, has often focused on individual cases because of the different pace of industrial and urban development and is thus dominated by national perspectives. In this paper, I elaborate on transnational exchange processes and local adaptations and transformations. I focus on the transfer of the housing model of SOMCO in Mulhouse, (a French house building association) during social international congresses. I examine whether cross-national networking enabled and facilitated the implementation of ideas on the local scale. I will elaborate on the transmission and the local adaptation of the Mulhouse-model in Belgium. Convergences, divergences, and different factors that influenced the local transformations (personal choice, political situation, socio-economic circumstances) will be taken into account.
\end{abstract}

\section{Keywords}

Social housing, international social congresses, nineteenth century, Mulhouse 


\section{The Opposite of Dante's Hell? The Transfer of Ideas for Social Housing at International Congresses in the 1850s-1860s}

Carmen Van Praet - Liberaal Archief/Ghent University

\section{Introduction}

In 1855 two Belgian civil servants - Edouard Ducpétiaux and Auguste Visschers - published an influential report in which they registered information about "social housing". Assigned by the Belgian Permanent Commission of Benefit Societies, they examined and compared several housing schemes in different European cities. They concluded that the act of building "healthy, convenient and economic houses was one of the most powerful ways to solve the social question and to aid the working classes." (Ducpétiaux \& Visschers, 1855, p. 43) The issue of housing and hygiene "problems" of workmen in European cities in the $19^{\text {th }}$ century was closely linked to expertise in health policy. With the advent of industrialization, the question of developing adequate housing for the emergent working classes became more pressing than before. Moreover, the problem of unhygienic houses in industrial cities did not stop at the borders of a particular nation-state, sometimes literally as pandemic diseases spread out "transnationally". Historiography about social policy in general and social housing in particular, has often focused on individual cases because of the different pace of industrial and urban development, and is thus dominated by national perspectives (Burnett (1980), Cassiers (1989), Chevallier (2010), Flamand (1989), Guerrand (1967), Heller (1979), Huberty et al. (2000), Joos et al. (1984), Melling (1980), Plunz (1990), Rodger (1995), Smets (1977), Smit (2010), Stébé (1998), Tarn (1971), Tollet \& Janssens (2009), Van der Woud (2010), Wohl (1977), Wright (1985)). However, "transnational" influences also played a vital role in the development of social policy (Bayly et al. (2006), Clavin (2010), Heclo (1974), Iriye (2007), Kaisar (2005), Conrad (2011), Patel (2010), Rodgers (1998), Saunier (2008), Tyrell (2010). Moreover, Hu \& Manning (2010) contend that international forces conveyed basic ideas while national forces determined the timing and the specifics of the adoption of international models. Was this also the case for early housing models in the mid nineteenth century? Historiography generally considers two European capitals - London and Berlin - as trendsetters in the housing question since the 1860s (Van der Woud, 2010, p. 26). These German and English attempts to resolve deficiencies in the housing of the poorer classes e.g. the philanthropic housing enterprises of Sir Sydney Waterlow, George Peabody, Octavia Hill or Princess Alice of Hesse-Darmstadt - are considered as the nineteenth century "philanthropic blueprints" for social housing (Adam, 2004, p. 17). This paper, however, will focus on a small French city: Mulhouse in Alsace, where as early as 1853 a house-building association was found, which constructed a cité ouvrière (i.e. working class neighborhood). I will argue that this concrete example of Mulhouse spread transnationally as the best model to solve the housing problem on Social International Congresses in Europe during the second part of the nineteenth century. How did this model fit into the political and moral agenda of a group called "hygienists", and how did it contribute to the conceptualization and crystallization of social policy? Can we argue that the circulation of ideas on housing schemes lay at the very basis of the development of social housing as a policy (Chambon, Johnstone, \& Köngeter, 2015). Some scholars have stated that "ideational processes" help construct the 
social problems most social policies are designed to address (Mehta (2011), Béland \& Orrenstein (2013). Moreover, these authors showed how ideas helped actors to define their interest and how they also shaped the understandings that underpin political action. I will focus on the transnational circulation of the Mulhouse-model across borders by examining several archival sources: international newspapers, brochures, bulletins, reports of international congresses, administrative documents and the correspondence of the housing association. Firstly, I will outline the proliferation of Social International Congresses. In the second part of this paper I will examine the sources of inspiration of the Mulhousian entrepreneurs, especially the first Great Exhibition in London (1851) as a platform for the exchange of ideas will be taking into account. After that, I will look at the particularities of the Mulhouse model put forward by an international network of experts or "hygienists". In the final part of this paper I will focus on the transfer and local adaptation of the Mulhouse cité ouvrière by several Belgian cities. Convergences and divergences will be taken into account, and I will look for the different factors that influenced the local transformations ranging from personal choice, over political situation, to socio-economic circumstances.

\section{Proliferation of Social International Congresses}

With the advent of industrialization, the question of developing adequate housing for the emergent working classes was a topical subject. In the 1840 s, a series of reports of doctors from different countries revealed the dismal living conditions of the working class (e.g. Villermé for France, Heyman and Mareska for Belgium, and Chadwick for England). The "abominable hygiene", the "moral degeneration" and "health consequences" of the paupers living in the slums were very much alike in every industrializing metropolis. It is not coincidental that the number of international congresses on hygiene and social topics expanded substantially in the course of the nineteenth century (Randeraad \& Leonards, 2010). The topic of social housing was also tackled on an international scale by a group of young progressive doctors, labeled as "hygienists". They developed "social medicines" when examining the new imperceptible threats to society caused by industrialization and urbanization, e.g. industrial fumes, food adulteration, water infections, and pollution of the sole (Velle, 1986, p. 266), (Verbruggen, 2002, p. 6). In their opinion, the changing conditions made medical expertise vital (Fressoz, 2007, p. 342). This group of doctors called for reforms, first in medical science, then in society as a whole. They turned their attention to the natural environment and its possible connection with individual pathological problems (Walton, 2005, p. 91). Moreover, they feared that the poor environmental conditions could lead to the "degeneration" of mankind (Tollebeek, Van Paemel, \& Wils, 2003, p. 24). The hygienists advocated better public health and recommended "well-ventilated, bright houses, healthy sewer systems, and waterworks" (Van der Woud, 2010, p. 71). During the second half of the nineteenth century, hygiene was a leading force that was ready to take charge of everything, and the question of adequate housing was a vital part of it (Latour et al., 1993, p. 23). However, "public health" and "social housing" were not yet institutionalized in this period (Houwaart, 1991, p. 19). Moreover, the two concepts crystallized during discussions on the local, the national, and even on the international level. It was not a coincidence that when the social question was abundantly discussed at the local and national levels (in medical 
associations and public health boards), the number of international congresses on these topics expanded substantially as well. These international congresses increasingly offered the opportunity to stage, debate and interchange ideas about social challenges more efficiently (Van de Perre, 2008, p. 1).

The earliest international congresses almost exclusively considered peaceful settlements of international conflicts. Gradually, from the 1850s onwards, international "Welfare", "Sanitary", and "Social Sciences" congresses, together with international congresses on other themes (e.g. prison reform, prostitution, education, alcoholism, slavery, political economy and statistics) outshined peace conferences. Although these conferences treated a broad array of themes, there were entanglements between them, as they were all linked to the social question (Van Daele \& Müller, 2013, p. 1300). The multiplication of international congresses must be placed within the trend of "scientification" of the society during the second half of the nineteenth century. International gatherings were a manifestation of the construction of several fields of expert knowledge (Haas, 1992, p. 1). Whereas the international congress in the 1850s-1860s discussed a multitude of topics, the congresses in the 1870s-1880s became more specialized. The congresses organized by the Association international du progrès des sciences sociales (i.e. International Social Science Association, ISSA) from 1862 to 1865 can be quoted as an example of the first type of comprehensive congresses. These international congresses promoted an encyclopedic approach to a holistic social reform project (Van Praet \& Verbruggen, 2015, p. 12). Also, since 1856 International Welfare Congresses were organized that dealt with a variety of topics - e.g. alcohol restrictions, charitable and philanthropic institutions, saving banks, sanitary ameliorations, public assistance, workman's associations, cooperative associations, and house building associations. The adherents to the comprehensive congresses were doctors, lawyers, architects, manufacturers, engineers, academics, politicians, economists, and owners or, in sum, a large group of people worried about, occupied by, and/or engaged with the improvement of the "fate" of the workingman. From the late 1860 s more specialized international congresses were organized, such as the International Medical Congresses. During these gatherings different medical branches - ranging from surgery, anatomy, and physiology to gynecology, obstetrics, ophthalmic sciences, dermatology, psychiatry, and even homeopathy - were discussed and formed. Every part of the human body became an object of study. Not surprisingly, medical academics and doctors almost exclusively composed the list of members of the International Medical Congresses.

Moreover, society as a whole became itself became an object of study during the second part of the nineteenth century (Tollebeek, Nys, \& De Smaele, 2002). Besides the purely scientific International Medical Congresses, other social congresses were organized, in which the medical knowledge and discourse offered a "solution to the social question". Between 1876 and 1884, a conference aiming specifically at hygiene questions took place every two years. These Sanitary and Welfare Congresses formed a transnational platform and a laboratory for hygienists. Unlike the exclusively scientific International Medical Congresses, the International Hygienic Congresses in the 1870s-1880s also hosted other actors. Hygienists, sanitary reformers and physicians gathered with lawyers, architects, civil engineers, economists, and industrials to deal with the unhygienic conditions in the growing 
European cities. Their weapon of choice was not a microscope; it was statistics. They wanted to "count" the world, in order to "cure" it (Velle, 1986, p. 265), (Wolffram, 2010, p. 113), (Randeraad, 2006). Statistics uncovered the causal relation between cholera and unhealthy living conditions. Moreover, the predictable pattern of systemic observations contributed to the hygienists' belief that human society could be controlled and managed (Randeraad, 2001, p. 54-55). During these international gatherings, participants formulated what they saw as "universal knowledge about the social question" and distributed it by means of congress reports, brochures, essays, and journals (Wolffram, 2010, p. 112). The conferees were influenced by other initiatives as they looked across their national borders for inspiration. The interchange of ideas and practices and the successful foreign examples were used as a lever to put pressure on policymakers at home. The International Social Congresses in the second half of the nineteenth century thus formed laboratories for social ideas (Rasmussen, 1990, p. 120). But they were also hubs in a diffuse and unstructured network of hygienist and social reformers, or part of what Pierre Yves Saunier (2008) has called the "first circulatory regime" in the field of social policy, characterized by "the interchange of words and experiences, in order to resist, devise, support or change the response to problems stemming from the industrial and urban revolution."

\section{Philanthropic Tourism: the Fieldwork of Social Reformers visiting Housing Projects}

The two Belgian commissioners Ducpétiaux and Visschers attended several international congresses, but besides that, they also visited several housing projects in different European industrial cities, such as Paris, Berlin, London and Mulhouse (Ducpétiaux \& Visschers, 1855, p. 4). They thus took part in what was called "philanthropic tourism" (Dupont-Bouchat, 2002). After their "fieldwork" and after inspecting and examining different projects they made recommendations about social housing. Ducpétiaux and Visschers noted that the Benefit building societies in Great Britain that collected financial means for the constructions of houses were a great example and they also referred to the Gemeinnützige Baugesellschaft, a building company in Berlin. But the most significant enterprise of all, Ducpétiaux and Visschers thought, was a housing project in Mulhouse. This French cité ouvrière was in their opinion "the most comprehensive example they had visited". How did this rather small industrial city obtained the status of an international example for these Belgian housing reformers?

During the first half of the nineteenth century, Mulhouse had developed a diversified economic base, characterized by textile and metallurgical enterprises. The city not only underwent important economic changes, but also "suffered" - as the hygienists in the nineteenth century formulated it - from a "demographic explosion": a tripling of the population from about 10.000 to 30.000 inhabitants in less than fifty years. Natural increase was not the only cause; the decisive factor was immigration (Borghese, 1980, p. 57-58). Mulhouse expanded into one of the most advanced centers and was called the France's Manchester (Northern Star, 03-07-1847, p. 8). Hygienist and entrepreneurs stated that, as a result of this important demographic explosion, the living conditions of the working classes were "atrocious". The overcrowded quarters were havens for pandemic diseases such as 
typhoid fever, tuberculosis and cholera (Van der Woud, 2010, p. 87). Louis Villermé - a leading French hygienist - visited Mulhouse in 1835 and 1836 and was appalled by the "squalor of the workers living in the town" (Fox, 1984, p. 147-148). Doctor Villermé was not the only one being concerned with the living conditions of the laborers. A group of large manufacturers of Mulhouse gathered in the Société Industrielle de Mulhouse (SIM) was "disturbed" by the situation as well. This association endorsed the dictum that "a boss owes more than wages to his workers" and they sponsored charitable and philanthropic works, ranging from homes for the elderly to public baths and associations to prevent industrial accidents (cf. Figure 1). The SIM also aspired to offer cheap, affordable and decent houses for the working classes. The factory-owners realized that the rents generally exceeded workers' wages and they wanted to avoid their employees moving to nearby villages. The industrialist André Koechlin was the first to build low cost worker tenements in 1835 (Borghese, 1980, p. 81-82). Just as in other industrializing regions, these piecemeal philanthropic measures were adequate instruments of control (Thompson, 2002, p. 711), (Kott, 1988, p. 35). Moreover this philanthropic work was determined by a latent desire of the new industrials to integrate themselves into the leading circles of urban society (Adam, 2004, p. 17). Furthermore, the Mulhouse captains of industry also believed that they had to look for solutions to solve the social question, in order to keep the central state away and to preserve their freedom and their interests (Kott, 1987, p. 655), (Kott, 1991, p. 153).

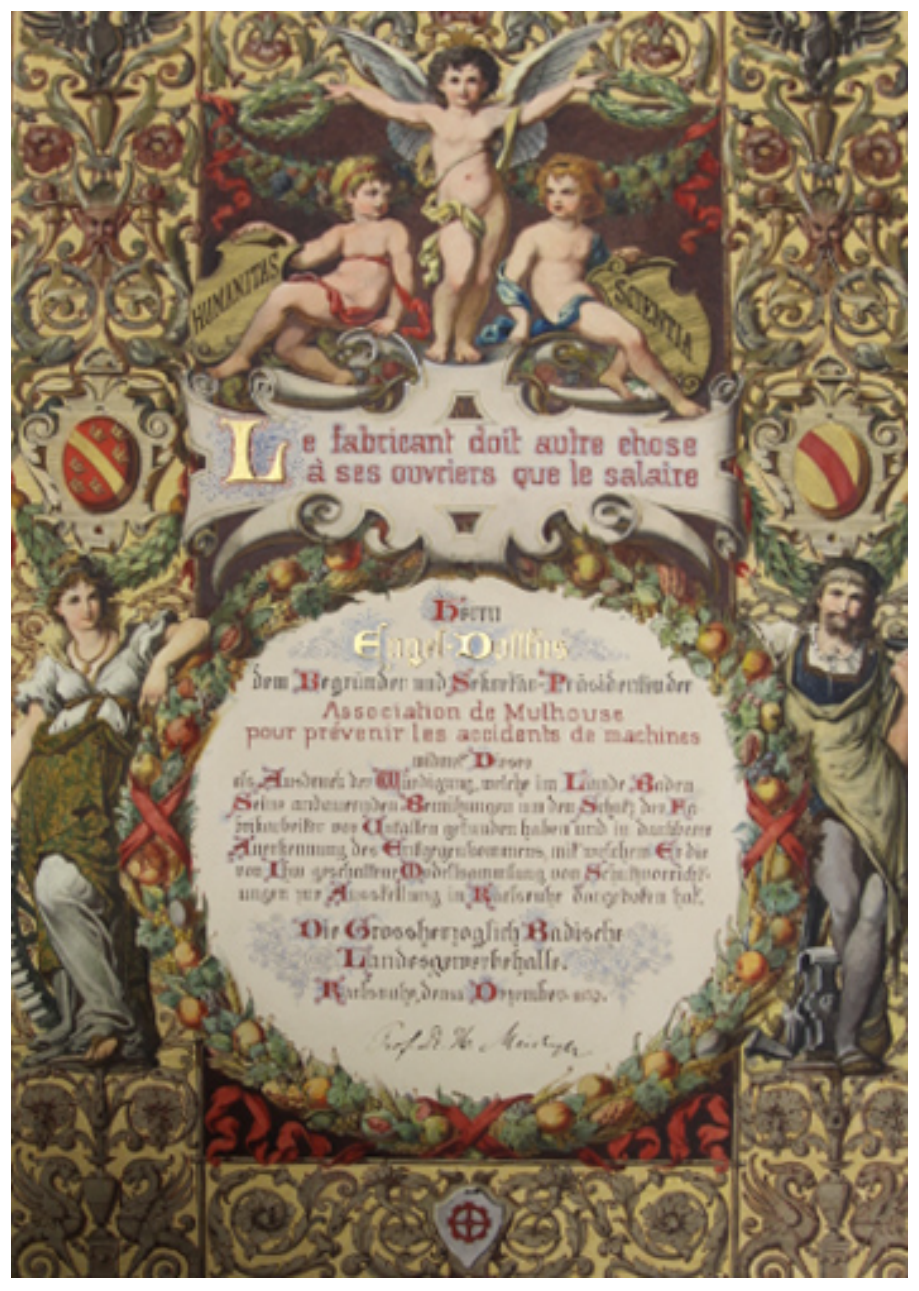


Figure 1: Engel-Dolffus established the "Association de Mulhouse pour prévenir les accidents de machines" because he believed that "A Boss owes more than Wages to his Workers".

In search of good practices, the members of the SIM looked abroad at better housing solutions for their laborers. A deputation of the SIM visited the Great Exhibition of Industry of all Nations in London in 1851. During this trip to London, the deputies of Mulhouse were introduced to the cottage projects executed by the British architect Henry Roberts. Roberts was the honorary architect for the Society for Improving the Condition of the Labo[u]ring Classes of London (SICLC), a powerful association that made attempts to reform urban housing. In 1850 Henry Roberts wrote an essay called The dwellings of the labo[u]ring classes, in which he described the advantages and the inconveniences of several building systems (Marcus, 1999, p. 234-235). The huge and cheap buildings were intended to hold dozens of houses (e.g. tenement houses, barracks, or union-houses), and had the inconvenience that living together too closely resulted in protests, disputes, and irregularities. He argued that the aggregation of a large number of people on the same spot and in close proximity led to unfavorable results (Norfolk News, 20-10-1866, p. 5). Roberts advocated for "separate, spacious and salutary" family houses with more privacy, in blocks of 4, 6 or 8 houses. For the Great Exhibition in 1851 Henry Roberts designed such a model-block for the SICLC in Hyde Park (Shapiro, 1985, p. 163).

After their visit to the Crystal Palace the Mulhousian entrepreneurs launched a competition for the building of affordable and decent housing for workers near the industrial site (Bulletin de la SIM, 1851, p. 135). The French architect and civil engineer Emile Muller (1823-1889) won. The construction of Muller's design started in 1853, under the aegis of a brand-new association, the Société Mulhousienne des Cités Ouvrières (SOMCO) (Polasky, 2010, p. 48). There were twelve founder-shareholders in this house building association and the mayor of Mulhouse - Jean Dollfus - was the president. Even though Muller received much credit for this housing-model, his design of the industrial town certainly was inspired by and derived from Henry Roberts' conception (Fox, 1984, p. 153). In this housing model, attention was paid to the importance of a sewage system, to space and light and to the circulation of fresh air ("Brochure of model houses", p. 2-3). Thus, the Great Exhibition in London constituted a site for international exchange. The transfer of Roberts' ideas also was facilitated by the fact that the president of France - Louis-Napoleon - requested to translate the essay of Roberts into French. The library of the SIM possessed a copy Roberts' book on housing models, and we can assume that Emile Muller consulted this work when he set up his own housing model. In fact, the French architect Muller even recommended Roberts' The dwellings of the labo[u]ring classes during international meetings as a "guiding manual" for everyone that wanted to improve the housing of the laborers ("Report of the Congrès International de Bienfaisance", 1856, p. 100, 457). The admiration was mutual: in a widespread publication in 1855 Roberts stated that the new project in Mulhouse blossomed to become an international model of a working class neighborhood.

The project in Mulhouse received international attention and the expectations were high, but the cite ouvrière project was certainly not the only housing project that circulated internationally in the nineteenth century as an example or model. During the Social 
International Congresses it was common to put forward local and national reform ideas, initiatives, discursive experiences and practical examples as international solutions to the social question (Van Daele \& Müller, 2013). In September 1856, an International Welfare Congress was held in Brussels, and the founding fathers of Mulhouse - Jean Dollfus and doctor Achille Penot - were on the guest list. In a discussion about housing the poor, the international conferees collected and exchanged information about six housing projects. First on line was a French housing project of Jules Emile Scrive in Lille. Secondly, two housing projects from Belgium were discussed: the project of the Grand Hornu erected by coal industrials in Hainaut and the project of La Vielle-Montagne set up by zinc industrials in Liège. Subsequently, a philanthropic and religious housing project in Groningen (Holland) and a model working class neighborhood in Copenhagen (Denmark) were presented. The final project was that of Jean Dollfus and Achille Penot. They discussed the technical and practical sides aspects of the cité ouvrière in Mulhouse. Despite a lot of similarities between these six projects, the cité ouvrière in Mulhouse was the most eye-catching. It was particularly interesting because it combined two specific characteristics: first of all, the project had not been carried out by a single manager, but by a group of Mulhousian patrons gathered in a house building association (SOMCO). Secondly, the workers could become owners of their rented houses after years of saving. The method behind the plan was straightforward: the SOMCO bought land and built houses, taking advantage of buying wholesale and of building on a large scale (London Daily News, 20-10-1866, p. 5). Subsequently, the tenants could become owners of the houses after fifteen years of mortgage payments (i.e. in practice by means of a monthly payment of 15 to 20 francs as installments or annuities). After the International Welfare Congress in 1856, a British newspaper even gave the following account: "The system now most approved of by philanthropists and labo[u]rers is that of small dwellings, designed for the least possible number of households, in which privacy, as a rule, will predominate over a life in common. This is the system applied in the cités ouvrières of Mulhouse, in France, which has been adopted by the building societies in England, and has served as a basis for institutions of alike nature in the different capitals of Europe. What most recommends this system to the favo[u]r of the working classes is the idea it holds out the possibility of each person becoming a owner" (Morning Post, 01-11-1856).

\section{The Opposite of Dante's Hell? Mulhouse, a Utopian Working Class Neighborhood in France}

The model in Mulhouse was in favor because it was congruent with hygienists' discourse: everything that could "cause the outspread of pandemic diseases" was cast aside. Doctor Penot strengthened this "hygienic" discourse on the International Welfare Congress by showing that only a small amount of cholera cases were diagnosed in the cité ouvrière when a pandemic made a lot of victims in Mulhouse in 1854. However, the question of dwelling houses was treated as more than a purely sanitary one. The initiators in Mulhouse had economic motives as well, and one of the key motives of the industrial manufacturers was to increase the labor productivity ("Report of the International Social Science Association", 1863, p. 541). Thus, social housing was from its beginnings more than just a philanthropic act. Besides personal benefits for the factory-owners, better housing and urban planning were 
also means to control the working class and prevent social disorder. More specifically, from 1847 until 1851 Mulhouse experienced several uprisings (Fox, 1984, p. 151). The first riot broke out in June 1847 and was prompted by the high prices of food, which in their turn were caused by a potato blight in 1845 and poor weather conditions. The situation deteriorated after the fall of the July Monarchy of France in February 1848. The popular agitation became increasingly organized, indicating the pervasiveness of socialist republican propaganda among the lower classes (Borghese, 1980, p. 63). This troubled situation comprised the catalyst for the industrialists in Mulhouse. Furthermore, during the international congresses, the importance of the 48-revolution as an eye-opener was put forward ("Report of the International Social Science Association", 1863, p. 558). The paternalistic captains of industry in Mulhouse feared a social revolution, which would threaten and undermine their hegemony (Borghese, 1980, p. 70, 75). This urged them to take measures to improve the living conditions of their laborers. Moreover, in 1852 the national government of France issued two decrees in which 10 million francs were granted for the improvement of the working-class houses in the large industrial cities. Private persons and associations could receive subsidies, and the Mulhousian house building association received in total 300.000 French francs from the national government to execute Muller's designs (Ducpétiaux, Visschers, 1855, p. 15). More specifically, this subsidy of the central government had to be used to build roads, sidewalks, and fountains as well as to plant trees (Penot, 1867, p. 12). For the Mulhousian entrepreneurs the lines between personal benefits, philanthropy and social welfare, between discipline and humanitarianism, and between paternalism and emancipation, were thin and permeable. Furthermore, they also received state support.

During the international conferences the first social reformers and hygienists examined the best models to obtain an ideal bourgeois society according to an elitist blueprint, e.g. a cité ouvrière housed "model" workers in "model" dwellings. Just as the entrepreneurs of Mulhouse, these international experts clung to upper class values, and considered themselves as new moral authorities. In their opinion the cité ouvrière of Mulhouse led to moral advantages, because the laborers were encouraged to maintain "the garden of their new house instead of going to the pub" and, because they could become owners, they would be less revolutionary ("Report of the Congrès International de Bienfaisance", 1856, p. 95-99). The tension between social work as a force for social regulation and as a force for social development or emancipation was thus never far away (Thompson, 2002, p. 711). The cité ouvrière in Mulhouse was a total concept holding everything required for health, comfort and for social order. The industrial city contained blocks of four houses, each with an enclosed, small garden. The SOMCO also recognized the importance of clean water and installed a water distribution system. More "social" buildings were constructed as well, such as a kindergarten, homes for the elderly, a hospital for disabled workers, public baths, places for laundry, a swimming pool, a popular library, a communal kitchen, a cooperative bakery and a grocery shop. There were also factory-schools, where young children were educated during their paid hours of work mutual aid funds were set up. When ill, the workers who engaged in the fund received $50 \%$ of their wage, together with medication and a free doctor consultation. Some Mulhousian industrials also handed out a retirement pay to their old, sick or invalid workers. In sum, the cité ouvrière in Mulhouse encouraged the three "pillars" of progressive 
liberalism in order to solve the social question. Instruction was promoted by the factoryschools and the public library; precaution and saving were stimulated by the mutual aid funds. And by paying the monthly annuities for their houses, property could be attained. By extending these extralegal benefits, self-help was stimulated. It was a liberal conception of helping the poor: by enlarging and encouraging the civil society, the social question could be "solved" without direct state intervention. The initiatives in Mulhouse in the 1850s differed from the early century philanthropic initiatives set out to appease the workers. "Once a man becomes a owner," stated Mulhousian architect Muller, "he will blush to eat the bread of charity" (Morning Post, 01-11-1856, p. 3). But even though the cité ouvrière of Mulhouse contained social emancipation elements, it still remained to some extent a paternalistic initiative.

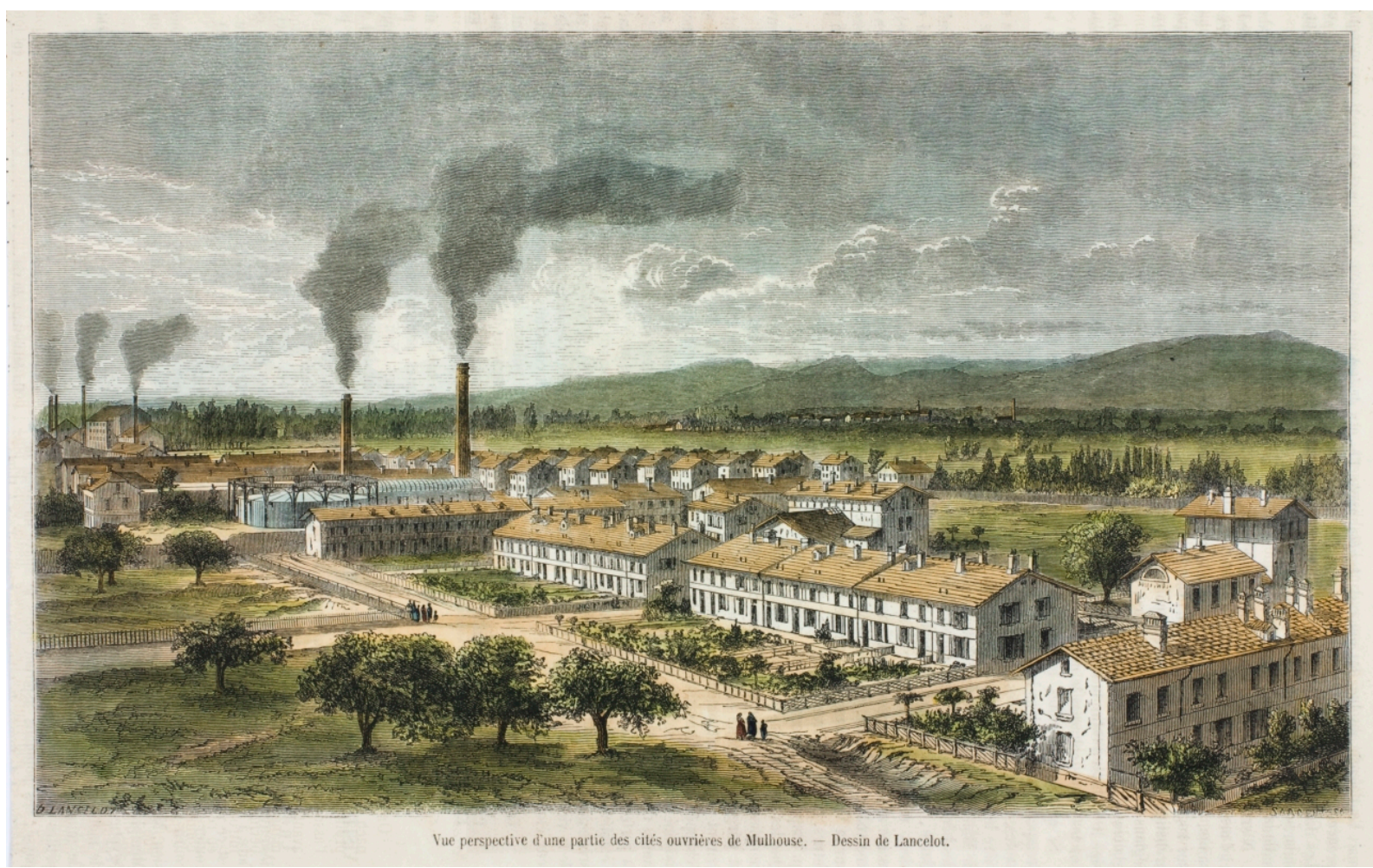

Figure 2: view on a part of the cités ouvrières de Mulhouse

Mulhousian doctor Achille Penot was not the only one attending international congresses to promote and to legitimize the cite ouvrière model. Other delegates of SIM and SOMCO were present at several international congresses as well. Jean Dollfus and Emile Muller attended the International Welfare Congresses in Brussels (1856), in Frankfurt (1857) and London (1862). Moreover, both men actively participated in the discussions on the housing question during these gatherings. Architect Muller offered practical tips about the cités ouvrières at the International Welfare Congress in 1856. Again, Muller did not take all the credit for his project as he emphasized that Henry Roberts was his source of inspiration During his contribution, Muller also referred to several other house-building initiatives in Belgium (e.g. Grand Hornu, Société John Cockerill, Société de la Vieille-Montagne), and to measures taken in several industrialized cities (Berlin, Bremen, Amsterdam, The Hague, Geneva, Stockholm, Copenhagen, Turin, Rome, New-York) ("Report of the Congrès 
International de Bienfaisance", 1856, p. 457-470). Jean Dollfus made his international appearance during the debates of the International Welfare Congress in London (1862). He presented a long and exhaustive report (similar to that of doctor Penot in 1856), in which he enumerated all initiatives made by industrialists in Mulhouse (cf. municipals schools, public baths, refuges for old and disabled workers, kindergartens, mutual aid funds, public library, cooperative grocery shops). Moreover, Jean Dollfus - categorized by the press as "the humane employer" - also introduced a new regulation allowing women to be absent during childbirth and six weeks after, in order to diminish the heavy rate of mortality among the infant children (Manchester Courier, 20-12-1864, p. 3). What made the measure progressive was the fact that Dollfus did not suspend the mothers' wages. In 1862, the delegates of Mulhouse were pleased to state that "the cité ouvrière" had already fond a lot of imitators ("Report of the Congrès International de Bienfaisance", 1862, p. 342-348). The project in Mulhouse received a lot of international appreciation. After attending the International Welfare Congress in London in 1862, the Belgian liberal Gustave Rolin-Jaequemyns stated that Mulhouse was the opposite of Dante's hell: "Hope, redemption by work is the device that could be inscribed at the entrance of this good place. It is as beautiful as Utopia, as eloquent as a fact" ("Letter from London written by Rolin-Jaequemyns, 10th of July 1862"). That same year, during the International Congress of the Social Sciences Association, Ducpétiaux argued that the model of Mulhouse was very successful. In 1864 more than 4/5 of the houses were already the property of a laborer. During the World Exhibition in 1867 in Paris, the SOMCO built a scale model of the model houses at Champ-de-Mars. A lot of visitors from other European countries visited the project from Mulhouse and more than 15.000 booklets about the project were handed out to the visitors. During this World Exhibition the SOMCO received a gold medal and architect Muller received a silver one ("Etats des constructions des cités et extraits des rapport Jean Dollfus", 1866-1867). For the captains of industry of Mulhouse, such international attention also had personal benefits and an economic motive: by spreading their model, other, foreign textile entrepreneurs could follow their example and in this way the international competition would be fairer (Kott, 1991, p. 56). The housing project in Mulhouse also implied a potential investment opportunity for entrepreneurs who wanted to diversify their deposits. In 1882 the SOMCO had built 1016 houses of which 706 were redeemed by the laborers. Even in the literature, Mulhouse received the status of a utopian working class neighborhood. The main character in Tolstoy's Anna Karenina (1877) visited Mulhouse in his search for a better society (Smit, 2007, p. 98).

\section{Small Scaled Housing Projects in Belgium influenced by Mulhouse}

In contrast to France, the revolutionary breeze of 1848 did not break through in Belgium. This lack of social pressure could explain why "social housing" was not high on the political agenda in the second half of the $19^{\text {th }}$ century. However, we can detect some minor measures. In 1849 the liberal Minister of the Interior, Charles Rogier provided credits for "slum clearances" and obliged the municipalities to found local Comités de salubrité that should examine the local situation and made proposals for improvement (Van Causenbroek, 1998, p. 11). Rogier also was the driving force of the National Congress on Public Hygiene in Brussels in 1851, which commissioned Ducpétiaux and Visschers to write the 
abovementioned report on the housing question. Moreover, local governments especially felt responsible for the housing question, in particular for the Bureau de Bienfaisance (i.e. local charitable institutions). In this part we will examine how the transnational circulation of the Mulhouse-model had an impact on the development of social housing policy in Belgium. Convergences and divergences will be taken into account, and I will look for the different factors that influenced the local transformations. I will also discuss the effectiveness of the measures.

29 April 1859. During a council meeting the Bureau de Bienfaisance of Nivelles decides to invest financial reserves into building 12 "healthy" houses for workers. Inspirer of this idea was doctor François Lebon (1807-1900) who attended the International Welfare Congress in Brussels in 1856 where he became inspired by the reports of Penot, Dollfus and Muller from Mulhouse ("Bureau de Bienfaisance de Nivelles: projet de logements destinés aux ouvriers", 1859). The architect of this first Belgian housing project was Raymond Carlier (1805-1883) who followed "hygienic" prescriptions conscientiously, e.g. the houses in Nivelles had an ingenious ventilation system. The project of Carlier in Nivelles showed a lot of architectural similarities with the houses in Mulhouse, but there was one important difference, determined by the local socio-economic context. When a laborer of Mulhouse registered for a house built by SOMCO, he had to have a starting capital. Consequently, the houses built by the SOMCO were mostly set up for a middle class of laborers, artisans and craftsmen. In Nivelles by contrast, the members of the Bureau de Bienfaisance stipulated that everyone, even a laborer without savings could participate in the project, as helping the poor was one of the main tasks of this local institution. Just as in Mulhouse the housing of the poor by the Bureau de Bienfaisance of Nivelles had an important moral aspect: doctor Lebon stated that the selection of the 12 families was based on "their good behavior, good morals and dedication to work" (Lebon, 1878, p. 5, 11). The project in Nivelles was small-scaled but nevertheless innovative because of its accessibility. On the $26^{\text {th }}$ of October 1884,12 families were invited to the city hall of Nivelles for a solemn ceremony to celebrate their ownership of the houses after 23 years of "hard work and savings". The housing experts of Mulhouse, Emile Cacheux and Emile Muller (1889, p. 209), who published an international overview of housing schemes in the late nineteenth century, also acknowledged the importance of the system in Nivelles: "it was the first time that the principle of acquisition of property was introduced in Belgium". Lebon was thus a pioneer in Belgium and others soon followed his example. In 1860 the Bureau de Bienfaisance of Wavres built 12 houses for the working class, imitating the architectural and the financial principles of architect Carlier (De Royer de Dour, 1890, p. 229-231). Other local municipalities in Belgium followed: Hoei (1867), Melle (1867), Jodoigne (1868), Sleidinge (1870), Zomergem (1870), Morlanwelz (1873), and Blankenberge (1873) (“Rapporten van de Hoge Gezondheidsraad”, 1867-1873, pp. 561, 215$216,254,65,519-519)$. These small-scale projects had some characteristics in common: the laborer could become owner by means of a repayment plan, the Bureau de Bienfaisance appointed inspectors to guarantee social order and hygiene. Furthermore, the workers who bought the houses were prohibited to sell liquor, to open a pub in the house and they also had to maintain the garden. 
24 June 1851. In the city counsel of Ghent a pamphlet of city counselor Adolphe Burggraeve - also professor medical sciences of the university of Ghent and head of the Civil Hospital - is discussed (Burggraeve, 1851, p. 4). Ghent was - just as Mulhouse - a dynamic textile-city that grew spectacularly in a short period. Consequently, in the 1840 s two doctors Heyman and Mareska - already noted that Ghent was "polluted, overcrowded, insanitary, and disease-infested". Just as Villermé did for France, they noticed, "housing of the laborers was at its worst" (Heyman \& Mareska, 1845). Ten years later Aldophe Burggraeve started visiting the "slums" in Ghent repeatedly, and was time and again "appalled by the deprivation of the workers living there". In 1851 Burggraeve thus initiated the foundation of a house building association in Ghent, the Société Anonyme pour l'amélioration des démeures de la classe ouvrière. Proceeding from this association Burggraeve wrote the abovementioned pamphlet to the city council, in which he clearly endorsed the hygienists' discourse. Burggraeve looked for disturbing and "unhealthy" elements in the natural environment of the laborers and connected them with the pathological problems of this group. He listed all "unhealthy" quarters of the city of Ghent, marked by "overcrowding, pollution, infections, and the total absence of light and air". As a remedy, Burggraeve advocated improving or even demolishing the unhealthy quarters and building new and "healthy" cités ouvrières modèles. In his view, a perfect workers district had public baths and lavatories, sanitary installations, and water pumps. Each house had also its own little garden, because, and here I quote Burggraeve, "it was a manner of moralization and a useful distraction to keep the workers away from pubs and other immoral places." A kindergarten and a school were part of his plans as well, because "instruction would moralize the laborers from childhood on" (Burggraeve, 1851, p. 7). In this project Burggraeve vaguely referred to initiatives in France and England, yet he did not explicitly name the two influential architects Henri Roberts or Emile Muller. However, we can state that Burggraeve was influenced by the international trend to build private houses for the laborers. Just as Roberts and Muller, doctor Burggraeve opposed tenement houses - or what he called bataillons-carrés - and he promoted separate, spacious and hygienic houses. Despite Burggraeve's efforts and persuasion, the first housing association in Ghent was never erected (Stynen, 2010, p. 348). Whereas Dollfus and the other shareholders in Mulhouse had enough political and socio-economic power to establish their house building association, Burggraeve had less influence. Firstly he did not find enough financial sponsors for his project and he did not received any national state subsidies. Secondly, Jean Dollfus exercised the role of mayor in Mulhouse whereas Burggraeve played only a minor role in the local of Ghent politics as city counselor and commissioner in local commissions on public health.

But Burggraeve continued his inquiries into social housing and attended several international congresses in the 1850s, among which the International Welfare Congress in Brussels in 1856 where the Mulhousian doctor Penot extensively described and glorified the Mulhouse project. During the congress of the International Social Science Association in Brussels and Ghent (1862/1863) Burggraeve complied with the Mulhouse model. Moreover, he strived to re-establish a housing association in Ghent, this time inspired by the SOMCO. This shows how Burggraeve used the transnational circulation of ideas as a vehicle to influence local social policy development. However, just as in Nivelles, Burggraeve also did not adopt the Mulhouse model indiscriminately. Burggraeve was not convinced by the idea of 
making every laborer owner of his house. In his view, this measure could lead to inconveniences, such as dependency to a factory-owner. The workman could also be inclined to take a loan on the house and becoming dependent to speculators, or the laborer would not have enough resources to finance the high maintenance costs (Burggraeve, 1864, p. 51). In sum, Burggraeve stated that the Mulhouse model was too expensive and too luxurious, certainly for a city as Ghent, where the mayor parts of the labors were poor factory workers ("Report of the International Social Science Association", 1862, p. 509-511) (Burggraeve, 1862, p. 262-265), (Burggraeve, 1886, p. 38). In the adapted Ghent-model, Burggraeve distinguished two categories of workmen: his housing association should contain "ownerlaborers" and "share-holder laborers". The craftsmen who could become owners of their house constituted the first category of laborers. The factory workers were part of the category of shareholders: they had not enough means to become owners, but they were members of the association and with membership they could rent houses from the housing association and also received an interest of $4 \%$ and a dividend of $1 \%$ from the association (Journal de Gand, 23-01-1864). In 1864 Burggraeve published this idea in a collected work on "Improvements to the Living Environment of Workers" (Améliorations de la vie domestique de la classe ouvrière). This time the association even had a broader outlook. It was not solely concerned with healthy workmen's dwellings, but would also make large acquisitions of food in order to resell it to the associated laborers at a reduced price, following the principle of a consumers' co-operation society. This project called the Société Gantoise would also create public baths and lavatories, a health center, kindergartens, evening schools, and mutual aid and precaution funds. Not just the association, but the local government as well had an important role to provide all the resources that contributed to salubriousness and public health. In 1866 Burggraeve published Projet d'assainissement et d'embellissement de la ville de Gand, in which he stated that the local government was responsible for clearing out the small streets and laying out large and spacious boulevards. The local government also had to provide good street lightening, clean water, and it had to protect the air purity. But just as ten years before, also in the 1860s Burggraeves ideas and proposals were not put into practice. He remained unable to implement new legislation in his hometown.

Beside the housing projects in Nivelles and Ghent, the question of "unhealthy slums" was also put forward in Verviers in the 1860s, and again, the model of Mulhouse influenced the social reformers in this small Belgian community. In 1861 the Société verviétoise pour la construction des maisons d'ouvriers was founded. Moreover, the national government exceptionally approved this association and it thus received the juridical statute of a public limited company. Just as Heyman, Mareska and Villermé the project in Verviers took form after a doctor - named André-Joseph Lepas - stated that the living conditions of the laborers were at their worst and had a "deteriorating effect on the morals of these people" (Lepas, 1844). Some industrials in Verviers felt responsible for this housing problem and directly contacted the captains of industry of Mulhouse. On the $4^{\text {th }}$ of March 1861, the Chamber of Commerce of Verviers sent a letter to the SIM with a question for more practical information and advice about the SOMCO ("Correspondance, registres de copier de lettres de SIM", 1861). In July of the same year, the association built nine houses for workers. There were a lot of architectural and institutional similarities with the project in Mulhouse: the project in 
Verviers was consisted in individual family homes with a little garden, attention was paid to fresh air and the laborer could become owner of his home after years of saving. But in contrast to Mulhouse, this project in Verviers was not at all successful. One of the members of the board of the Société verviétoise - Emile Bède (1869) - made a report about the problems of this organization to inform other social reformers. First of all, the laborers in Verviers were not enthusiastic about this housing project. They considered the houses too much as charity. Moreover, the price of the houses was too high. In 1867 the shareholders of Verviers visited the World Exhibition in Paris and had a lot of attention for the model houses built by the SIM on the Champ-de-Mars. In the summer of 1868 the Société verviétoise again built four new houses, this time almost exactly modeled after the project in Mulhouse. But again, small changes were made to adapt the model to the social and cultural environment of Verviers. Bède inserted a model to make the investment in the laborer houses financially interesting for the entrepreneurs in Verviers. Contrary to the SOMCO, the Société verviétoise could make profit. Just as the Bureau de Bienfaisance of Nivelles, this housing association in Verviers became a model for other Belgian cities. In June 1867 the Belgian government voted a law by which building companies could receive the juridical status of a limited public company (Bertrand, 1888, p. 135-148). On the 21th of September 1867 the Société liégeoise des habitations was erected after the model of the Société verviétoise (Quarles van Ufford, 1873, p. 876-877). That same year, Antwerp housing companies were established in Brussels and Antwerp (d'Andrimont, 1871, p. 81).

In the second part of the nineteenth century there were thus several housing projects in Belgium, but contrary to the successful international model of Mulhouse, these small-scaled local projects were mere drops in the ocean. Several Belgian specialists and reformers became frustrated and wanted greater structural reforms. During a meeting of the Liberal Association in Brussels (1864) the liberal Ernest Defuisseaux advocated a proactive policy that would replace the emergency measures that were taken when a cholera epidemic broke out. Although a number of housing models circulated and the project of Mulhouse was well known in Belgium, the housing theory was not put into practice until the late 1880s, when a new national law on workers houses was enacted. In contrast to Mulhouse, there was for a long time no social pressure in Belgium to make structural changes or to formulate national housing laws. Whereas the international congresses had no direct impact on Belgian national law in the 1850s and 1860s they were nevertheless influential. When a violent strike broke out in March 1886, the national Belgian government organized a large national survey to obtain information about social and housing questions (Steensels, 1977, p. 454). A Workers Commission (Commission du Travail) was initiated to investigate the working conditions of laborers and workmen's houses were closely inspected (Denys, 1974, p. 401). One of the research questions of this commission was to detect whether the model of Mulhouse was imitated in Belgium ("Rapporten van de Hoge Gezondheidsraad", 1887, p. 109-110). As a result of these surveys, in 1889 the national government promulgated a law on the housing of the laborers. The central goal of this housing law was to make the worker the owner of his house, an idea that had already been transnationally spread in the 1850-60s, and that resembled the Mulhouse-model. The housing law of 1889 also revealed that the legislator disassociated from the idea of direct government intervention. Just as in Mulhouse, public 
limited companies - or more general the civil society - had to play a role in building housing for the poor ("Rapporten van de Hoge Gezondheidsraad", 1887, p. 128). Yet, the law also contained new elements, e.g. regional Patronage committees were founded, and a national saving bank - the General Savings and Annuity Fund (cf. Algemene Spaar- en Lijfrente Kas) - was involved in financing the enterprise. This saving bank would not lend money to private persons but to public corporations. The housing question soon got enclosed within the national context of pillarization in Belgium. Several house-building associations erupted within every "ideological pillar". A lot of social, Catholic, and liberal public corporations on housing arose in Belgian cities in the 1890s and housing of the poor became a type of policy making. In 1894 the Catholic minister of public works Léon De Bruyn ranked 64 housing corporations in Belgium (Meerens, 1896, p. 44-48).

\section{Conclusion}

At Social International Congresses it was common to put forward local and national reform ideas, initiatives, discursive experiences and practical examples as international solutions to the social question. International hygienists and other social reformers picked up the idea of Mulhouse, as they believed that "improved houses make improved men, women and children". The Mulhouse model was in favor because it was consonant with hygienists' belief that human society could be controlled and managed. It was a total concept holding everything required for health, comfort and for social order.

The paternalistic captains of industry in Mulhouse had several motives to set up these cités ouvrières. The factory-owners realized that the rents generally exceeded workers' wages and they wanted to avoid their employees moving to nearby villages. But there was definitely also a latent desire of the new industrials to integrate themselves into the leading circles of the urban society. They had economic motives as well such as increased labor productivity. But probably the most important reason why they came into action was the fear of a social revolution, which would threaten and undermine their hegemony. Better housing and urban planning were means to control the working class and prevent social disorder. Moreover, it was a solution for the social question, in order to keep the central state away and preserve their freedom and their interests. In sum, by building "decent and hygienic" houses for their own laborers, the social question could be "solved" without direct state intervention. In order to gain legitimacy, the entrepreneurs of Mulhouse promoted their model at international congresses and World Exhibitions, they published booklets with practical information and gave personal advice to sympathizers by means of letter correspondence. For the entrepreneurs of Mulhouse, the international attention also had economic benefits: by spreading their model, other, foreign textile entrepreneurs could follow their example, and international competition would be fairer.

The project in Mulhouse was particularly interesting because it combined two specific characteristics. First of all, it was not carried out by a single owner, but by a group of Mulhousian patrons gathered in a house building association. Secondly, the workers could become owners of their rented houses after years of saving. The model also led to moral advantages, since it encouraged instruction, precaution and saving. We can conclude that the project of Mulhouse was internationally propagated as a model in the second part of the 
nineteenth century. The interchange of ideas and practices and the successful foreign examples were used as a lever to put pressure on policymakers at home. But as the case of the Belgian cities proved, local forces determined the timing and the specifics of the adoption of this international model. In contrast to Mulhouse, there was for a long time no social pressure to make structural changes or to formulate national housing laws in Belgium. Although actors in several Belgian cities used the transnational circulation of the Mulhouse-model as a vehicle to influence local social policy development, it was not a guaranty for success, as the case of Adolphe Burggraeve in Ghent showed. However, the circulation of ideas on housing schemes lay at the very basis of the development of social housing. The national housing law of 1889 clearly contained elements and ideas that had already been transnationally spread in the 1850$60 \mathrm{~s}$ and that resembled the Mulhouse-model. At the end of the nineteenth century however, a remarkable shift took place. In the 1850 s and 1860s top-down solutions for the laborers were put forward. In the 1880s, however, the laborers themselves played a more active role, though the argumentation was simple and the focus on self-help remained: "Personne mieux que l'ouvrier lui-même ne connaît les besoins du prolétariat; c'est relever son caractère que de lui permettre de s'aider lui-même" (De Royer de Dour, 1890, p. 131). 


\section{List of references}

Adam, T. (2004). Philanthropy, Patronage and Civil Society: Experiences from Germany, Great Britain and North America. Bloomington: Indiana University Press.

Bayly, C., Beckert, S., Connelly, M., Hofmeyr, I., Kozol, W., \& Seed, P. (2006). AHR conversation; On transnational history. American Historical Review, 111, 1440-1464. doi:10.1086/ahr.111.5.1441

Bède, E. (1869). Note sur les travaux de la société verviétoise pour la construction de maisons d'ouvriers, Verviers: Vinche.

Béland, D., \& Orenstein, M.A. (2013). International Organizations as Policy Actors: An Ideational Approach. Global Social Policy, 13 (2), 125-143. doi: 10.1177/1468018113484608

Bertrand, L. (1888). Le logement de l'ouvrier et du pauvre en Belgique, Brussel.

Borghese, A. (1980). Industrialist Paternalism and Lower-class Agitation. The case of Mulhouse, 1848-1851. Histoire Sociale, 13 (25), 55-84.

Brochure of model houses. See: Archives Municipales de Mulhouse, Fonds SIM (02 B 31).

Bulletin de la SIM (1851). 116 (24)

Burggraeve, A. (1851). Projet de cités d'ouvriers pour la ville de Gand, Gent: De Busscher.

Burggraeve, A. (1862). Etudes sociales, Brussel: Lacroix.

Burggraeve, A. (1864). Amélioration de la vie domestique de la classe ouvrière, Gent: De Busscher.

Burggraeve, A. (1866). Projet d'assainissement et d'embellissement de la ville de Gand, Gent: Annoot-Braeckman.

Burggraeve, A. (1886). Concours Guinard pour l'amélioration de la position matérielle et intellectuelle de la classe ouvrière en general et sans disctinction, Gent.

Burnett, J. (1980). A social history of housing, 1815-1970, London: Methuen.

Cassiers, M. (1989). Bruxelles, 150 ans de logements ouvriers et sociaux, Brussel: Dire.

Chambon, A., Johnstone, M., \& Köngeter, S. (2015). The circulation of knowledge and practices across national borders in the early twentieth century: a focus on social reform 
organisations. European Journal of Social Work, 18:4, 495-510. doi:10.1080/13691457.2014.953041

Chevallier, F. (2010). Le Paris moderne: histoire des politiques d'hygiène, 1855-1898, Rennes: Presses universitaires de Rennes.

Clavin, P. (2010). Time, Manner, Place: writing Modern European History in Global, Transnational and International Contexts. European History Quarterly, 40 (4), 624-640. doi: $10.1177 / 0265691410376497$

Conrad, J. (2011). Social Policy history after the transnational turn. In P. Kettunen \& K. Petersen (Ed.), Beyond welfare state models: Transnational historical perspectives on social policy (pp. 218-240). Cheltenham: Edward Elgar.

d'Andrimont, L. (1871). Des institutions et des associations ouvrières de la Belgique, Brussel: Lebègue.

Defuisseaux, E.N.J. (1864). Conférence du 4 mai 1864 sur les habitations ouvrières, Brussels: Decq.

Denys, L. (1974). Trends in de sociaal-ekonomische toestand van de Belgische arbeiders rond 1886. Belgisch Tijdschrift voor Nieuwste Geschiedenis, 5 (3-4), 361-425.

De Royer de Dour, H. (1890). Essaie d'étude d'économie sociale. Les habitations ouvrières en Belgique, Brussel: Société Belge de Librarie.

Ducpétiaux, E., \& Visschers, A. (1855). Rapport de la commission permanente des sociétés de secours mutuels sur les combinaisons ayant pour but de faciliter aux ouvriers l'acquisition d'habitations convenables, Brussel: Lesigne.

Dupont-Bouchat, M.S. (2002). Du Tourisme Penitentiaire a 'l'Internationale des philanthropes'. La creation d'un reseau pour la protection de l'enfance à travers les congrès internationaux (1840-1914). Paedagogica Historica, 38 (2-3), 533-563.

Flamand, J.P. (1898). Loger le peuple: essai sur l'histoire du logement social en France, Paris: La Découverte.

Fox, R. (1984). Science, Industry, and the Social Order in Mulhouse, 1798-1871. The British Journal for the History of Science, 17 (2), 147-148.

Fressoz, J.B. (2007). Beck Back in the 19th Century. Towards a Genealogy of Risk Society. History and Technology, 23 (4), 333-350. 
Guerrand, R.H. (1967). Les origines du logement social en France, Paris: Les editions ouvrières.

Haas, P.M. (1992). Introduction: Epistemic Communities and International Policy Coordination. International Organization, 46 (1), 1-35.

Heclo, H. (1974). Modern Social Politics in Britain and Sweden: From Relief to Income Maintenance. New Haven: Yale University Press.

Heller, G. (1979). 'Propre en ordre': habitation et vie domestique 1850-1930: l'exemple vaudois, Lausanne: Editions d'en-bas.

Heyman, J., \& Mareska, D.J. (1845). Enquête sur le travail et la condition physique et morale des ouvriers employés, Gent: Gyselynck.

Houwaart, E.S. (1991). De hygiënisten: artsen, staat \& volksgezondheid in Nederland 18401890, Groningen: Historische Uitgeverij.

Hu A., \& Manning, P. (2010). The global social insurance movement since the 1880s. Journal of Global History, 5, 125-148.

Huberty, C., Hoflack, M., \& Moureaux, P. (2000). 100 ans de logement social à Molenbeek: bilan et perspecives d'avenir, Brussel: Le logement molenbeekois.

Iriye, A. (2007). The transnational turn. Diplomatic History, 31 (3), 373-376.

Joos, L., van Doorne, G., \& Bisschop, M.L. (1984). Volkshuisvesting in Gent. Tentoonstelling naar aanleiding van 80 jaar Gentse maatschappij voor huisvesting, Gent: Stad Gent.

Journal de Gand, 23-01-1864

Kaisar, W. (2005). Transnational Mobilization and Cultural Representation: Political Transfer in an Age of Proto-Globalization, Democratization and Nationalism (1848-1914). European Review of History, 12 (2), 403-424.

Kott, S. (1987). Enjeux et significations d'une politique sociale: la Société industrielle de Mulhouse (1827-1870). Revue d'histoire moderne et contemporaine, 34 (4), 640-659.

Kott, S. (1988). La Haute-Alsace: Une région modèle en matière d'habitat ouvrier (18531914). La Revue de l'Economie Sociale, 27-35.

Kott, S. (1991). Des philanthropies aux politiques sociales. Solutions françaises et allemandes à la question sociale en Haute-Alsace (1850-1914) (Unpublished master's thesis). Sorbonne, Paris. 
Latour, B., Sheridan, A., \& Law, J. (1993) .The Pasteurization of France, Cambridge: Harvard University Press.

Lebon, F. (1878). Des habitations ouvrières à Nivelles. Moyen pratique de faciliter aux classes laborieuses l'accès du capital et de la propriété, Nijvel: Guignardé.

Leonards, C., Randeraad, N. (2010). Transnational Experts in Social Reform, 1840-1880. International Review of Social History, 55 (2), 215-239.

Lepas, A.J. (1844). Coup d'oeuil sur la situation de la classe ouvrière de Verviers, Brussel: De Mortier.

London Daily News, 20-08-1867.

Manchester Courier, 20-12-1864.

Marcus, S. (1999). Apartment Stories: City and Home in Nineteenth-Century Paris and London, Berkeley: University of California Press.

Meerens, L. (1896). Etudes pratique sur les habitations ouvrières en Belgique et le fonctionnement des sociétés d'habitations ouvrières dans leurs rapports avec la caisse générale d'épargne et de retraite suivie de la loi du 9 août 1889 coordonnée et des arrêts et circulaires utiles à son interprétation, Brussel: Bruylant.

Melling, J. (1980). Housing, social policy and the state, London: Croom Helm.

Mehta, J. (2011). From 'Whether' to 'How'. The Varied Roles of Ideas in Politics. In D. Béland, \& R.H. Cox (Ed.), Ideas \& Politics in Social Science Research, New York: New York University Press.

Morning Post, 01-11-1856.

Cacheux, E., Muller, E. (1889) Les habitations ouvrières en tous pays, Paris: Baudry.

Norfolk New, 20-10-1866.

Northern Star, 03-07-1847.

Patel, K.K. (2010). 'Transnational History'. European History Online.

Penot, A. (1867). Les cités ouvrières de Mulhouse et du departement du Haut-Rhin. Nouvelle edition augmentée de la description des bains et des lavoirs établis à Mulhouse, Mulhouse: Bader. 
Plunz, R. (1990). A history of housing in New York City: dwelling type and social change in the American metropolis, New York: Columbia University Press.

Polasky, J. (2010). Reforming Urban Labor. Routes to the city, roots in the country, Ithaca: Cornell University Press.

Randeraad, N. (2006). Het onberekenbare Europa. Macht en getal in de negentiende eeuw, Amsterdam: Wereldbibliotheek.

Randeraad, N. (2011). The International Statistical Congress (1853-1876). Knowledge transfers and their limits. European History Quarterly, 41 (1), 50-65.

Rasmussen, A. (1990). Jalons pour une histoire des congrès internationaux au XIXe siècle: régulation scientifique et propagande intellectuelle. Rélations internationales, 61, 115-133.

Report of the Congrès International de Bienfaisance, Brussels, 1856.

Report of the International Social Science Association, Brussels, 1862.

Report of the International Social Science Association, Ghent, 1863.

Rodger, R. (1995). Housing in urban Britain, 1780-1914, Cambridge: Cambridge University Press.

Rodgers, D.T. (1998). Atlantic Crossings: Social politics in a progressive age, Cambridge: Harvard University Press, 1998.

Saunier, P.Y. (2008). Les regimes circulatoires du domaine social 1800-1940: projets et ingénierie de la convergence et de la différence. Genèses, 71 (2), 4-25.

Shapiro, A.L. (1985). Housing the Poor of Paris, 1850-1902, Wisconsin: Madison.

Smets, M. (1977). De ontwikkeling van de tuinwijkgedachte in België: een overzicht van de Belgische volkswoningbouw in de periode van 1830 tot 1930, Brussel: Mardaga.

Smit, C. (2007). International reform literature. Indictment, guidance and inspiration. In S. Couperus, C. Smit, D.J. Wolffram (Ed.), In control of the city: local elites and the dynamics of urban politics, 1800-1960 (93-105). Leuven: Peeters.

Smit, C. (2010). Symbols and Images of the Amsterdam Housing Issue. In I. Van den Broek, C. Smit, D.J. Wolffram (Ed.), Imagination and Commitment. Representations of the Social Question, Leuven: Peeters. 
Stébé, J.M. (1998). Le logement social en France (1789 à nos jours), Paris: Presses Universitaires de France.

Steensels, W. (1977). De tussenkomst van de overheid in de arbeidershuisvesting: Gent, 1850-1904. Belgisch Tijdschrift voor Nieuwste Geschiedenis, 8 (3-4), 447-500.

Stynen, A. (2010). Proeftuinen van burgerlijkheid. Stadsnatuur in negentiende-eeuws België (Unpublished doctoral dissertation). KULeuven, Leuven.

Tarn, J.N. (1971). Working-class housing in 19th-century Britain, London: Lund Humphries for Architectural Association.

Thompson, N. (2002). Social Movements, Social Justice and Social Work. British Journal of Social Work, 32 (6), 711-722.

Tollebeek, J., Nys, L., \& De Smaele, H. (2002). De Zieke natie: over de medicalisering van de samenleving 1860-1914, Groningen: Historische Uitgeverij.

Tollebeek, J., Vanpaemel, G., \& Wils, K. (2003). Degeneratie in België 1860-1940: een geschiedenis van ideeën en praktijken, Leuven: Leuven University Press.

Tollet, A., \& Janssens, P. (2009). Vilvoorde City, meer bepaald in de Far-West: sociale huisvesting, Leuven: Peeters.

Tyrell, I. (2010). Reflections on the Transnational Turn in United States History: Theory and Practice. Journal of Global History, 4, 453-474.

Van Causenbroeck, B. (1998). Rode Daken. De Goede Werkmanswoning 75 Jaar, Gent: Amsab.

Van Daele, J., \& Müller, C. (2013). Peaks of internationalism in social engineering: a transnational history of international social reform associations and Belgian agency, 18601925. In Beyond Belgium: Encounters, Exchanges and Entanglements (1900-1925) - special edition of $B T F G$, Brussels.

Van de Perre, S. (2008). These mutual lessons of nation to nation. The International Philantropic Congresses of 1856, 1857 and 1862. Conference paper Voluntary Action History Society Liverpool.

Van der Woud, A. (2010). Koninkrijk vol sloppen: achterbuurten en vuil in de negentiende eeuw, Amsterdam: Bakker. 
Van Praet C., \& Verbruggen, C. (2015). 'Soldiers for a joint cause': a relational perspective on local and international educational leagues and associations in the 1860s. BMGN, Low Countries Historical Review, 130 (1), 4-24.

van Ufford, Q.J.K.W. (1873). Iets over arbeidswoningen. De Economist, 22 (2), 876-877.

Velle, K. (1986). Medikalisering in België in Historisch Perspectief: een inleiding. Revue belge de philologie et d'histoire, 64 (2), 256-285.

Verbruggen, (C. (2002). Stank bederft onze eetwaren. De reacties op industriële milieuhinder in het 19de-eeuwse Gent, Gent: Academia Press.

Walton, J.K. (2005). Histories of Tourism. Representation, Identity and Conflict, Frankfurt: Channel View Publications.

Wohl, A.S. (1977). The eternal slum: housing and social policy in Victorian London, London: Arnold.

Wolffram, D.J. (2010). Deftige Hervormers. Internationale congressen van statistici en hygiënisten in de 19e eeuw. In M. Broersma, J.W. Koopmans (Ed.), Identiteitspolitiek. Media en de constructie van gemeenschapsgevoel (pp. 111-124). Hilversum: Velden.

Wright G. (1985). Building the dream: a social history of housing in America, Cambridge: Mass. 